\title{
Market Orientation, Learning Organization and Dynamic Capability as Antecedents of Value Creation
}

\author{
Hanif Mauludin, Taher Alhabsji, Syafii Idrus, Zainul Arifin \\ ${ }^{1}$ Malangkucecwara School of Economic. Indonesia \\ ${ }^{1}$ Brawijaya University. Indonesia \\ ${ }^{1}$ Brawijaya University. Indonesia \\ ${ }^{1}$ Brawijaya University. Indonesia
}

\begin{abstract}
Strategic competitiveness is achieved when a firm successfully formulate and implement a strategy of value creation. In order to create competitive advantage, the theory of competitive advantage have contributed to the present two major schools of the Market-Based View (MBV) and Resources-Based View $(R B V)$, which both lead the company in creating a competitive advantage through superior value. The purpose of this paper is to examine the relationship between market orientation, learning organization and dynamic capability on value creation. Using a questionnaire survey, the paper is based on data collected from 105 owners or managers of industry creative in Indonesia. The partial least squares (PLS) structural equation modeling approach was used to analyze the data and test the hypotheses. The results indicate that, among the market orientation, learning organization, dynamic capability are significantly and positively related to value creation.
\end{abstract}

Keywords: Value Creation, Dynamic Capability, Learning Organization, Market Orientation, Creative Industry.

\section{Introduction}

Strategic competitiveness is achieved when a firm successfully formulate and implement a strategy of value creation (Bharadwaj. et al., 1993, Hitt., 1997, Hoffman., 2000, Hill. 2007). In order to create competitive advantage, the theory of competitive advantage have contributed to the present two major schools of the MarketBased View (MBV) and Resources-Based View (RBV), which both lead the company in creating a competitive advantage through superior value creation. Value creation is intended for customers who are defined as the value of all benefits or qualities acquired by the customer relative to the price.

Value creation develops due to two aspects, price and quality. Both aspects are multidimensional in business systems. Business system is the configuration of resources (inputs), activities (throughput) and the products offered (output), all intended to create value for customers (Porter, 1993; Cravens., 2003; Dewit., 2005; Barney., 2007; Teece.2009 ). Value creation oriented company for the creation of customer value profitably. In the end, the company must have a strong market orientation culture (Craven 2003), a learning organization (Narver.1995) and have the ability to reconfigure resources controlled (Barney.2007; Teece. 2009).

Competition forces companies to better understand the needs and expectations of the customer and competitor behavior. Therefore the company should undertake continuous learning in order to gain knowledge and new ways to respond to market changes and demands. The company must also have the ability to move resources into distinctive competence for the company. Strong market orientation and a conducive learning environment and the ability to mobilize resources, the effort to create value-added (value creation) will be achieved superior.

Furthermore Dewit (2005) propose a preposition company must be able to provide products and services more closely to the needs of clients than the competition if they want to have a competitive advantage. Thus, a company must have a culture of strong market orientation and company should always learn to improve their knowledge of the business processes. That means that the market orientation and learning organization is a necessary factor in creating value creation in order to build competitive advantage.

Competitive environment in which the company operates also led to an increase in customer demand for the company to deliver superior value (Sanchez et al., 2009). Therefore, many companies see the value of customers as a key factor when looking for new ways to achieve and maintain a competitive advantage. Identify external and internal organizational capabilities is very important to enhance the creation of value for customers. Internally the organization should focus on improving the ability of resources including people. Externally, organizations must focus to see the customer as a key component in order to maximize the value created for them (Landroguez. 2011). Organizations need to understand the value of customers to be able to invest the appropriate resources to create customer value. This is important because wrong investment that will lead to wastage especially reseources capital. The emphasis of the creation of value for the customer is on 
understanding how companies can make cost savings through increased efficiencies and be able to make a difference attributes of products and services at competitive prices. Afuah (2002) defines customer value as the performance characteristics of a product as perceived by the customer, which is a function of the physical characteristics and capabilities that can meet the needs of customers.

In the context of market orientation, value creation is built on top of customer orientation, competitor orientation and coordination between departments within the company (Narver. 1995). Creating superior value oriented around the needs and expectations of customers that will result in customer satisfaction. Meanwhile, competitor orientation is needed for comparison. Two activities in the implementation of market orientation is used as a basis for deciding what products to match market conditions. Market orientation is a culture and a commitment to superior value creation process for consumers. With emphasis on the customer (customer focus), competitor intelligence, and cooperation and cross-functional involvement.

Successful implementation of market orientation is also supported by the ability to identify and expand the unique capabilities. Capability is a unified whole and complex that includes the skills and knowledge, which is carried out through a process of organizational and coordination of various activities and utilize its assets. Unique capacity has several requirements, including: (1) to contribute disproportionately to the superior value, (2) enables organizations to offer value to its customers in a more cost-effective, (3) superior to its competitors, (4) difficult duplicated competitors; and (5) can be applied to a variety of competitive situations.

Furthermore, in the context of dynamic capability, Danneels (2003) said that the company that creates valuable products should not rely on the needs of today's customers. In dynamic companies need to pay attention to the needs and expectations of potential customers to enrich the product information related to the desired value by the market. This means that companies are trying to expand the market but still able to focus on core products and development. This requires the support of the availability of the resources and the ability to configure a variety of resources towards the most economical composition.

Ability is also defined as the capacity of an integrated set of resources to perform a task or activity. Afuah (2004) says that companies need the ability to change (to convert) controlled assets into customer value creation. Capability is the result of an integrated resource groups (Hitt. 1996). Dewit (2005) assumes that capability as one of the important components for the company to profitability and the ability to produce as a source of competitive advantage. Capability leads to the ability or skill in combining the companies or controlled using various resources that ultimately led to the development of new products.

This study aimed to examine the relationship between market orientation, learning organization and dynamic capability on value creation. The study also evaluated the contribution cost leadership and differentiation strategies in the process of value creation.

\section{Market Orientation and Learning Organization}

Market-oriented firms are successful because they are able to outperform competitors due to their ability to better understand and respond to customer needs, through the effective management of hard-to-duplicate resources (Day, 1994; Farrell, 2008).

With regards the conceptualisation and measurement of market orientation, two perspectives have gained wide acceptance. The first, developed by Narver and Slater (1990) argues that a market orientation "is the organisation culture that most effectively and efficiently creates the necessary behaviours for the creation of superior value for buyers, and, this, continuous superior performance for the business". For Narver and Slater (1990), a market orientation comprises three elements: customer orientation, competitor orientation and interfunctional coordination. The second perspective was proposed by Kohli and Jaworski (1990) who define a market orientation as, "an organisation-wide generation of market intelligence pertaining to current and future customer needs, dissemination of intelligence across departments, and organisation-wide responsiveness to it"(Farrell, 2008).

Customer orientation is defined as an adequate understanding of the target customer to buy in order to create superior value for buyers continuously. Include an understanding of the entire value chain of the buyer at the current and future (Uncles, 2000).

Kirca et al. (2005) argue the market orientation can enhance organizational innovation and new product performance that is focused on customer needs. Based on a comprehensive meta-analysis, Kirca et al. (2005) found that market orientation affects the innovation company that have an impact on value creation (value creation), and also there is a positive relationship between market orientation and organizational performance.

Nevertheles, there are still a number of gaps and limitations of research instruments research on market orientation, but the logic of thinking that market-oriented firms will be able to establish the appropriate value customer expectations and this will have an impact on sustainable competitive advantage can be accepted. (Narver and Slater. 1990; Kohli and Jaworski. 1990; Hoffmann. 2000; Craven. 2003; Kirca et al; 2005; Fareel., 2008; Harris. 2003) 
Organizations must continue to learn from their past experience and must be willing to adapt to a new position if they are to survive and prosper. Becoming a learning organization is a relatively new trend in business that emphasizes problem solving systematically. it means that everyone in the organization involved in identifying and solving problems, enabling the organization to continuously improve and enhance its capabilities.

The term learning organization is defined in many ways. Sutherland (2003) defines as an organization in which people at all levels, individually and collectively, are continually increasing their capacity to produce work that they expect. Senge (1994) defines a learning organization as an organization where people continually expand their capacity to create the results they truly desire, where new patterns are maintained and expansive thinking. Skyrme (2003) viewed from the perspective of knowledge management (KM) defines a learning organization as an organization that has the systems, mechanisms and processes that are used to continuously improve the ability of organizations exist.

Chien et al (2008) uses the term learning orientation in their research showing that learning orientation is a necessary factor in enhancing the ability of innovation which in turn will impact on business performance. That means the learning organization as an organization skilled at creating, obtaining and transferring knowledge and modifying behavior to reflect new knowledge and insights. Thus the learning organization has been defined as an organization's ability to adapt to its environment when companies operate in an environment that seems to be increasingly more vulnerable to change. Conducive learning environment will encourage the individuals within the organization to share knowledge on an ongoing basis, to increase the added value for the organization. The accumulated value will enable the group to live and succeed in the current era of hyper competition. Competition is not only happening on a national level, but has led to the region and even globally the organization demanded more flexible, creative and able to learn in harmony. Like being an orchestra with a variety of sounds but still compact and adhere to the agreed rules.

\section{$H_{1}:$ Market Orientation (MO) effect on Value Creation (VC) \\ $\mathrm{H}_{2}$ :Market Orientation (MO) effect on the Learning Organization (LO) \\ $H_{3}:$ Market Orientation $(M O)$ effect on Dynamic Capability (DC) \\ $\mathrm{H}_{4}$ :Learning Organization (LO) effect on Value Creation (VC)}

\section{Dynamic Capability and Value Creation}

Several frameworks have been proposed to address fundamental questions in the field of organizational strategies such as how to achieve a sustainable competitive advantage. The most interesting frameworks proposed recently is the concept of Dynamic Capability (Teece et al, 1997; 2009) which is an extension of the resource-based view (RBV). This framework is relatively new and located in between several theories as Evolutionary Economics argued by Nelson and Winter (1982), who asked the question "How can the company grow over time." Resource-based view of the company "RBV", trying to answer "Why and how different companies through the heterogeneity of its resources. As well as Organizational Learning / learning organization is looking for an answer how companies capture and apply knowledge. (Barney. 1991; Kogut and Zander. 1992).

The concept of dynamic capabilities needed in formulating strategies in a rapidly fluctuating environment coupled high complexity, the need for innovation is high, and efforts to improve the organization's ability to cope with market dynamics. Key points in dynamic capability is the ability of the organization to develop, update and care for a variety of resources (including tangibles, intangibles and human resources) in order to create customer value.

Therefore the ability of dynamic linking skills and resources of the organization at this time with the external changes, strategy formulation and implementation, which leads to accuracy (fitness) between resources with the needs of a changing environment.

In broad scope, dynamic capability is the company's ability to integrate, build, and reconfigure internal and external competencies to address rapidly changing environments (Teece et al., 1997). Eisenhardt and Martin (2000) further identify dynamic capabilities as the firm-specific and typically associated with reconfiguration of the transformation of resources to cope with environmental change.

Dynamic capabilities perspective Suggests that in order to maintain a competitive advantage, companies not only need the ability to extract economic benefits from current resources and develop new skills, but also emphasizes the ability to coordinate, integrate, and reconfigure resources / assets and to develop new resources / assets to generate competitive advantage (Zhan and Luo, 2008)

Liu (2011) showed that the dynamic capabilities as antecedent factors for the development of organizational strategy in which managers alter their resource base, acquire, integrate, and combine resources to produce new value creation strategies (Value Creation.

Competitive advantage derived from the value or benefits that can be created for the buyers that the 
company is more than it cost the company to create it (Porter. 1993). Hollensen (2010) stated that creates a competitive advantage is a business benefit to customers through differentiation better than the competition and also an effort to obtain the most cost-efficient to be able to present competitive pricing policy.

The competitive environment in which the company operates also led to an increase in customer demand for the company to provide superior value (Sanchez et al., 2009). Therefore, many companies see the value of customers as a key factor when looking for new ways to achieve and maintain a competitive advantage. Identify external and internal organizational capabilities is very important to increase value creation for customers. Internally the organization should focus on improving the ability of resources including human resources as the main actor. Externally, the organization also must focus to see customers as the key component in order to maximize the value created for them (Landroguez. 2011).

The success of creating added value for customers will lead to customer retention and even loyalty. Revenue of the company can be improved even when the customer loyalty occurs. Thus, managers should pay attention to the creation of value as a potential source of corporate profits. Company creates value by coordinating the purchase of factor inputs with the sale of the company to the consumer. Companies generate value by providing products to customers through a variety of suppliers and input factors of production company itself. Value creation begins with the end consumer rather than the company's agent or retailer. The chain should also be considered by the company. Nominal size of these benefits is the customer's willingness to pay, which is defined as the maximum amount that the customer will pay for the product. Thus, the customer benefits are also referred to as the customer's willingness to pay.

Zou (2008) noted that create value for customers can be done through two presses which cost service emphasis and emphasis. Porter (1993) also directed the company to excellence differentiation or cost leadership as a base creating superior customer value. Differentiation can be done by creating different products, providing different services, or creating a product image that is unique and different from other competitors. Product differentiation strategy (differentiation), encourages companies to be able to find its own uniqueness in the market so the target. The uniqueness of the product (goods or services) that put forward this enables a company to attract maximum interest from potential consumers (Kim. 2011).

Completing the differentiation advantage, Porter (1993) also directs the company towards a low-cost strategy (cost leadership) emphasis on producing standard products (equal in all aspects) with the cost per unit is very low. In the hypercompetitive situation Baiya structure is a major concern for the company. However consumers will still price sensitive. To be able to run a low-cost strategy, a company must be able to meet the requirements of resources (resources) as well as the ability or capability of the organization. This strategy may only be run if it has some advantages in the field of corporate resources, namely: the availability of capital, skilled in process engineering, strict supervision, easily manufactured, as well as distribution and promotion costs low. While the capabilities of the organization, companies must have: the ability to tightly control costs, better control of information, incentives based on targets, reconfiguring the resources (Teece. 2009).

\section{$H_{5}$ : Dynamic Capability (DC) effect on Value Creation (VC)}

\section{Method}

The research was conducted in the creative industry for advertising and fashion group in Indonesia. Number of questionnaires that were collected were 105 respondents. Research instruments using an online questionnaire. Analytical techniques used Partial Least Square Structural Equation Model (SEM PLS) using SmartPLS software Ver. 2.0.

Measurement of research constructs (unobserved variables) performed through the reflective indicator measurement scale using a Likert Scale technique. Market orientation construct adopt MKTOR measurement of Narver and Slater (1990) and Harris (2003) is more comprehensive with 6 indicators.

Measurement of learning organization using the instrument developed by Watkins and Marsick and Song (2009) which has been proven validation and reliability in several studies, among others, in Korea by Yang. 2004, China by Zang et al, 2004, Taiwan by Lien et al. 2006 Latin America by Hernandez. 2006, and in U.S.oleh Ellinger et al. , 2003. This instrument is known as the dimensions of learning organization questionnaire (DLOQ)with 6 indicators. Dynamic Capability measured using indicators adapted from Cui et al. (2011). Moingeon (1996), Barney (1991; 2007), Teece (1997; 2009); Helfat et al., (2007), Afuah (2002), Zubac (2010) with 5 indicators. Indicators used to measure value creation adapted from Porter (1992), Best (2005), Zubac (2010)andZou(2008) based on service and cost emphasis with 10 indicators. All indicator will be shows in appendix 1 . 
Model Measurement (Outer Model)

\section{Analysis and Results}

This model specifies the relationship between the latent variable indicators. or it can be said that the outer model defines how each indicator relates to the latent variables. Tests conducted on the outer models include:

\section{Convergent Validity.}

Convergen validity value is the value of loading factor on the latent variable indicators. The expected value of > 0.7 . In table 1 shows that the value convergen validity on each indicator

Table 1. Outer Loadings (Mean, STDEV, T-Values)

\begin{tabular}{|c|c|c|c|c|c|}
\hline & $\begin{array}{c}\text { Original } \\
\text { Sample }(\mathrm{O})\end{array}$ & $\begin{array}{l}\text { Sample } \\
\text { Mean } \\
\text { (M) }\end{array}$ & $\begin{array}{c}\text { Standard } \\
\text { Deviation } \\
\text { (STDEV) }\end{array}$ & $\begin{array}{l}\text { Standard } \\
\text { Error } \\
\text { (STERR) }\end{array}$ & $\begin{array}{c}\text { T Statistics } \\
\text { (|O/STERR|) }\end{array}$ \\
\hline $\mathrm{dc} 1<-\mathrm{DC}$ & 0.873400 & 0.875569 & 0.020901 & 0.020901 & 41.787743 \\
\hline $\mathrm{dc} 2<-\mathrm{DC}$ & 0.851120 & 0.849724 & 0.020155 & 0.020155 & 42.229417 \\
\hline $\mathrm{dc} 3<-\mathrm{DC}$ & 0.866990 & 0.865803 & 0.022498 & 0.022498 & 38.537125 \\
\hline $\mathrm{dc} 4<-\mathrm{DC}$ & 0.810462 & 0.806472 & 0.041583 & 0.041583 & 19.490074 \\
\hline $\mathrm{dc} 5<-\mathrm{DC}$ & 0.813221 & 0.811180 & 0.029359 & 0.029359 & 27.699094 \\
\hline $104<-$ LO & 0.901594 & 0.902103 & 0.016595 & 0.016595 & 54.328278 \\
\hline lo1 <- LO & 0.831820 & 0.832682 & 0.036022 & 0.036022 & 23.092237 \\
\hline $102<-\mathrm{LO}$ & 0.837086 & 0.833767 & 0.035110 & 0.035110 & 23.841797 \\
\hline $103<-\mathrm{LO}$ & 0.735990 & 0.723088 & 0.060228 & 0.060228 & 12.219971 \\
\hline $105<-\mathrm{LO}$ & 0.867802 & 0.869162 & 0.018497 & 0.018497 & 46.916394 \\
\hline lo6 <- LO & 0.918415 & 0.916522 & 0.014692 & 0.014692 & 62.510372 \\
\hline $107<-\mathrm{LO}$ & 0.832691 & 0.833429 & 0.034687 & 0.034687 & 24.005738 \\
\hline mol $<-\mathrm{MO}$ & 0.858846 & 0.852813 & 0.034042 & 0.034042 & 25.229105 \\
\hline $\mathrm{mo} 2<-\mathrm{MO}$ & 0.894343 & 0.889926 & 0.022423 & 0.022423 & 39.884760 \\
\hline $\mathrm{mo} 3<-\mathrm{MO}$ & 0.874376 & 0.870999 & 0.028644 & 0.028644 & 30.525904 \\
\hline mo4<- MO & 0.918522 & 0.917218 & 0.017471 & 0.017471 & 52.573442 \\
\hline mo5 <- MO & 0.882138 & 0.879981 & 0.025854 & 0.025854 & 34.119624 \\
\hline mo6<- MO & 0.910858 & 0.909543 & 0.018029 & 0.018029 & 50.522640 \\
\hline mo7 <- MO & 0.831775 & 0.833183 & 0.019391 & 0.019391 & 42.895915 \\
\hline $\mathrm{vc} 1<-\mathrm{VC}$ & 0.804376 & 0.805257 & 0.027086 & 0.027086 & 29.697089 \\
\hline $\mathrm{vc} 10<-\mathrm{VC}$ & 0.857597 & 0.858090 & 0.022637 & 0.022637 & 37.885520 \\
\hline $\mathrm{vc} 2<-\mathrm{VC}$ & 0.832972 & 0.833691 & 0.030679 & 0.030679 & 27.151190 \\
\hline $\mathrm{vc} 3<-\mathrm{VC}$ & 0.863567 & 0.858571 & 0.030585 & 0.030585 & 28.235429 \\
\hline ve4 <- VC & 0.874787 & 0.872796 & 0.023058 & 0.023058 & 37.938750 \\
\hline $\mathrm{vc} 5<-\mathrm{VC}$ & 0.818963 & 0.816054 & 0.028171 & 0.028171 & 29.070947 \\
\hline ve6 <- VC & 0.822101 & 0.822995 & 0.035662 & 0.035662 & 23.052265 \\
\hline vc7 <- VC & 0.742191 & 0.737011 & 0.039102 & 0.039102 & 18.981022 \\
\hline $\mathrm{vc} 8<-\mathrm{VC}$ & 0.942862 & 0.941330 & 0.010762 & 0.010762 & 87.607368 \\
\hline $\mathrm{vc} 9<-\mathrm{VC}$ & 0.8 & 80 & 828 & 8828 & 1545 \\
\hline
\end{tabular}

All the indicators have outer loading greater than 0.5 and the t-statistic $>1,983(\alpha=5 \%)$. All indicators can be used in testing the research model because adequate convergent validity. 


\section{Discriminant Validity}

Discriminant Validity value is the value of cross loading factor that is useful to know whether the construct has adequate discriminant. By comparing the value of loading on the construct should be greater than the value of loading with other constructs.

Table 2. Cross Loadings

\begin{tabular}{|l|c|c|c|c|}
\hline & DC & LO & MO & VC \\
\hline dc1 & $\mathbf{0 . 8 7 3 4 0 0}$ & 0.555412 & 0.645539 & 0.736206 \\
\hline dc2 & $\mathbf{0 . 8 5 1 1 2 0}$ & 0.667429 & 0.568439 & 0.747430 \\
\hline dc3 & $\mathbf{0 . 8 6 6 9 9 0}$ & 0.611236 & 0.645638 & 0.730388 \\
\hline dc4 & $\mathbf{0 . 8 1 0 4 6 2}$ & 0.455607 & 0.647381 & 0.760079 \\
\hline dc5 & $\mathbf{0 . 8 1 3 2 2 1}$ & 0.561428 & 0.580754 & 0.740506 \\
\hline 104 & 0.663758 & $\mathbf{0 . 9 0 1 5 9 4}$ & 0.386546 & 0.590103 \\
\hline lo1 & 0.552912 & $\mathbf{0 . 8 3 1 8 2 0}$ & 0.265685 & 0.487649 \\
\hline lo2 & 0.524567 & $\mathbf{0 . 8 3 7 0 8 6}$ & 0.240589 & 0.491665 \\
\hline lo3 & 0.445122 & $\mathbf{0 . 7 3 5 9 9 0}$ & 0.107753 & 0.366638 \\
\hline lo5 & 0.644355 & $\mathbf{0 . 8 6 7 8 0 2}$ & 0.366913 & 0.598272 \\
\hline lo6 & 0.624007 & $\mathbf{0 . 9 1 8 4 1 5}$ & 0.371848 & 0.582697 \\
\hline lo7 & 0.513632 & $\mathbf{0 . 8 3 2 6 9 1}$ & 0.252082 & 0.444242 \\
\hline mo1 & 0.611828 & 0.268409 & $\mathbf{0 . 8 5 8 8 4 6}$ & 0.653120 \\
\hline mo2 & 0.619207 & 0.221181 & $\mathbf{0 . 8 9 4 3 4 3}$ & 0.698334 \\
\hline mo3 & 0.678968 & 0.280085 & $\mathbf{0 . 8 7 4 3 7 6}$ & 0.736073 \\
\hline mo4 & 0.664247 & 0.375953 & $\mathbf{0 . 9 1 8 5 2 2}$ & 0.770467 \\
\hline mo5 & 0.635884 & 0.300261 & $\mathbf{0 . 8 8 2 1 3 8}$ & 0.678424 \\
\hline mo6 & 0.645803 & 0.315003 & $\mathbf{0 . 9 1 0 8 5 8}$ & 0.751744 \\
\hline mo7 & 0.656756 & 0.385551 & $\mathbf{0 . 8 3 1 7 7 5}$ & 0.734276 \\
\hline vc1 & 0.693511 & 0.617833 & 0.595152 & $\mathbf{0 . 8 0 4 3 7 6}$ \\
\hline vc10 & 0.839894 & 0.687267 & 0.634611 & $\mathbf{0 . 8 5 7 5 9 7}$ \\
\hline vc2 & 0.680389 & 0.370749 & 0.691476 & $\mathbf{0 . 8 3 2 9 7 2}$ \\
\hline vc3 & 0.705927 & 0.510703 & 0.746448 & $\mathbf{0 . 8 6 3 5 6 7}$ \\
\hline vc4 & 0.740246 & 0.503689 & 0.750739 & $\mathbf{0 . 8 7 4 7 8 7}$ \\
\hline vc5 & 0.728749 & 0.471866 & 0.673036 & $\mathbf{0 . 8 1 8 9 6 3}$ \\
\hline vc6 & 0.655656 & 0.354205 & 0.743889 & $\mathbf{0 . 8 2 2 1 0 1}$ \\
\hline vc7 & 0.623885 & 0.295112 & 0.682962 & $\mathbf{0 . 7 4 2 1 9 1}$ \\
\hline vc8 & 0.882171 & 0.654265 & 0.730564 & $\mathbf{0 . 9 4 2 8 6 2}$ \\
\hline vc9 & 0.846340 & 0.623142 & 0.653196 & $\mathbf{0 . 8 7 2 5 3 1}$ \\
\hline & & & & \\
\hline
\end{tabular}

Table 2 shows that the correlation of constructs Market Orientation, learning organization, dynamic capability and value creation to each indicator is higher than the correlation with indicators of other constructs. This suggests that the latent constructs predict indicators on their blocks better than the indicator on the other block.

\section{Composite Reliability}

The third part is the outer composite reliability models to test the reliability of the indicator values to construct. Constructs would be reliable if the value of composite reliability and Cronbach alpha above 0.7.

Table 3. Composite Reliability

\begin{tabular}{|c|c|}
\hline & Composite Reliability \\
\hline DC & 0.924890 \\
\hline LO & 0.947054 \\
\hline MO & 0.960775 \\
\hline VC & 0.961265 \\
\hline
\end{tabular}

Composite reliability values in Table 3 exceeds 0.7. it means Indicators of Market Orientation, Learning Organization, Dynamic Capability, Value Creation, conclusively able to measure latent variables. 


\section{Structural Model (Inner Model)}

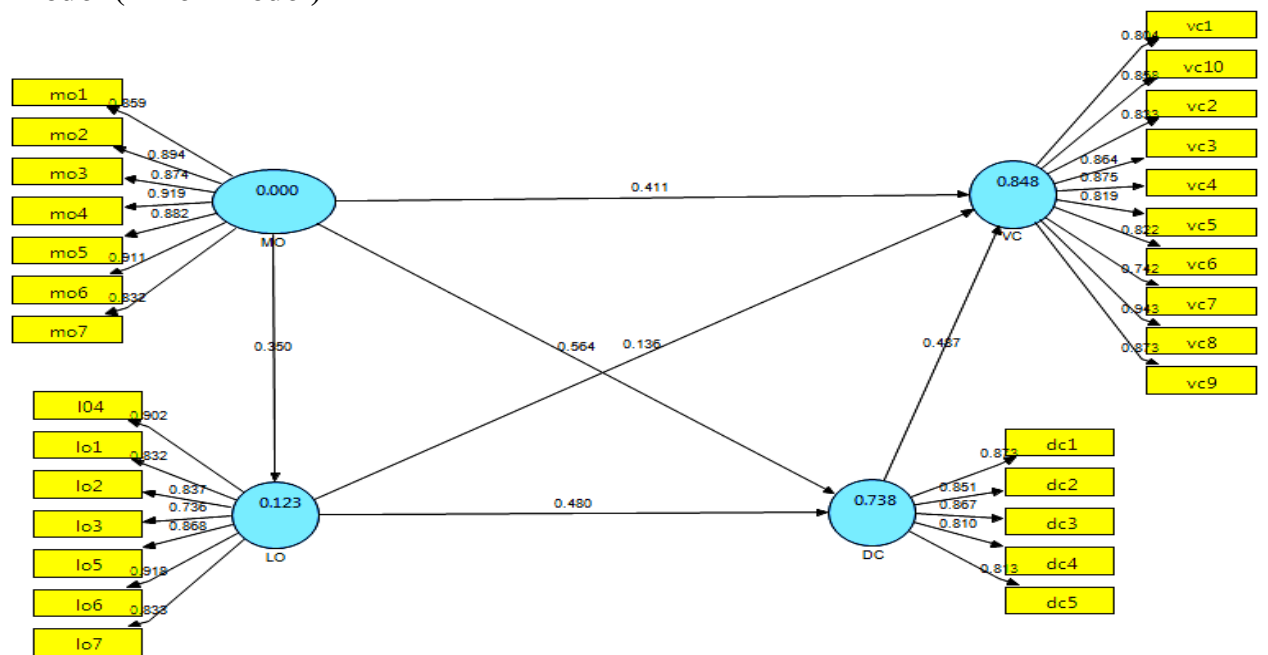

Figure 1. Overaal Model

Evaluation of the model using the R-square (R2) for the dependent constructs. R-square values reflect the overall predictive power of the model (Falk and Miller, 1992; Pirouz, 2006) to limit the R-square value is greater than 0.10 or greater than 10 percent (or goodness-fit of the model). By processing the data with PLS, the resulting value of the coefficient of determination (R-square) as follows in table 4.

Table 4. R Square

\begin{tabular}{|c|c|}
\hline Konstruk & R Square \\
\hline $\mathrm{DC}$ & 0.737897 \\
\hline $\mathrm{LO}$ & 0.122680 \\
\hline $\mathrm{MO}$ & \\
\hline $\mathrm{VC}$ & 0.847882 \\
\hline
\end{tabular}

Goodness of fit in PLS can be seen from the value of Q2. Q2 values have the same meaning as the coefficient of determination (R-square / R2) in regression analysis. The higher the R2, then the model can be said to be more fit to the data. Q-Square value greater than 0 (zero) indicates that the model has predictive relevance, whereas Q-Square value is less than 0 (zero) indicates that the model has less predictive. From table 4, it can be seen the value of Q2 at $0.96467(96.46 \%)$. These results meant that the structural model has predictive relevance is very high, the good and decent models to be used in the prediction.

\section{Hypothesis testing}

Table 5. Path Coefficients (Mean, STDEV, T-Values)

\begin{tabular}{|l|l|l|l|l|l|c|}
\hline \multicolumn{1}{|c|}{ PATH } & $\begin{array}{c}\text { Original } \\
\text { Sample (O) }\end{array}$ & $\begin{array}{c}\text { Sample } \\
\text { Mean (M) }\end{array}$ & $\begin{array}{c}\text { Standard } \\
\text { Deviation } \\
\text { (STDEV) }\end{array}$ & $\begin{array}{c}\text { Standard } \\
\text { Error } \\
(\text { STERR })\end{array}$ & $\begin{array}{c}\text { T Statistics } \\
(\mid \mathrm{O} / \text { STERR })\end{array}$ & $\begin{array}{c}\mathrm{P} \\
\text { value }\end{array}$ \\
\hline DC -> VC & 0.487353 & 0.472660 & 0.101041 & 0.101041 & 4.823324 & 0.000 \\
\hline LO -> DC & 0.479594 & 0.489209 & 0.049569 & 0.049569 & 9.675252 & 0.000 \\
\hline LO -> VC & 0.136337 & 0.145729 & 0.057194 & 0.057194 & 2.383749 & 0.019 \\
\hline MO -> DC & 0.564210 & 0.557837 & 0.059137 & 0.059137 & 9.540649 & 0.000 \\
\hline MO -> LO & 0.350257 & 0.351106 & 0.077113 & 0.077113 & 4.542114 & 0.000 \\
\hline MO -> VC & 0.411180 & 0.419694 & 0.092947 & 0.092947 & 4.423819 & 0.000 \\
\hline
\end{tabular}

Estimation results for the model inner direct influence between Dynamic Capability for Value creation statistic shows the t-value of 4.823324, where the value is greater than t-table. $1.9889 \alpha=5 \%$, it shows the influence of the Dynamic Capability Value creation is significant.

Inner estimation results for the model the direct influence of learning organization on Dynamic Capability indicates t-statistic value of 9.675252, where the value is greater than t-table. $1.9889 \alpha=5 \%$, it shows the influence of the Dynamic Capability learning organization is significant. 
Inner estimation results for the model the direct influence of the learning organization value creation shows the value of t-statistic of 2.383749 , where the value is greater than t-table. $1,988 \alpha=5 \%$, it shows the influence of the learning organization is a significant value creation.

Inner estimation results for the model the direct influence of the market orientation of the dynamic capability indicates t-statistic value of 9.540649, where the value is greater than t-tabel.1.9889 $\alpha=5 \%$, it shows the influence of market orientation on dynamic capability is significant.

Inner estimation results for the model the direct influence of market orientation towards learning Organization indicates t-statistic value of 4.542114, where the value is greater than t-tabel.1.9889 $\alpha=5 \%$, it shows the influence of the market orientation of the learning organization is significant.

Inner estimation results for the model the direct influence of market orientation toward value creation shows the value of t-statistic of 4.423819 , where the value is greater than t-tabel.1.9889 $\alpha=5 \%$, it shows the influence of the market orientation of the learning organization is significant.

\section{Conclusions and Discussion}

The concept of market orientation is proposed by Narver and Slater (1990), Kohli and Jaworski (1990) argue that market orientation is an organizational culture that most effectively and efficiently creates the necessary behaviors for the creation of superior value for customers and, sustained superior performance. Market orientation is also related to the organization's efforts on current market intelligence and the future of customer needs, dissemination of intelligence (result) in the entire department or organization in functions, and organization of a comprehensive response to the findings or information obtained.

The concept of market orientation can be defined as the activity of digging up information about customers and competitors as well as how to distribute the information to all parts of the organization in order to take action in accordance with its capacity of strategic action, but remain in the corridor coordination. This will affect the organization in the context of a learning organization. As expressed by Alkhafaji (2003) Organizations need to continue to learn from their past experience and must be willing to adapt to a new position if they want to survive sustainably. This means that every part of the organization involved in identifying and solving problems, enabling the organization to continuously improve and enhance its capabilities. This is consistent with the context of market orientation in terms of cross-functional coordination.

The research results of Lin et al (2008), Farrell (2008) and Zubac (2010) also proved that the market orientation significantly influence the learning organization. In line with the mindset, the implementation of market orientation also resulted in increased organizational capacity through increased ability to read or sensitive to new opportunities and to manage the impact of a possible threat yangmuncul market dynamics. This situation will force the company to reconfigure the various resources they have in order to be a renewable source of competitive advantage. Dynamic capability, including the ability of the company needed to adapt to changes associated with the customer demands and technological opportunities. (Zhan and Luo., 2008; Cui et al. 2011; Afuah.2002; Zubac.2010).

Implementation of market orientation within the company will play a role in value creation. The core of value creation is a comparison between the value of the sacrifice benefits. Not an easy task for a company to be able to realize the concept of value creation. However, a good understanding of market orientation will yield information on the needs of customers as well as the performance of competitors. On this basis the company can design a program of value creation more effectively. In order to create customer value, the company must be a solution provider, is more than just a seller of products or services (Best 2005).

Furthermore, organizations that implement a Learning Organization always supply the organization with new ideas and new information that comes from the environment, employee development and other relevant sources. Further knowledge of new ideas and information that should be transferred throughout the organization elements. So that a change in organizational behavior as a result of new knowledge. Such a mechanism is needed within the framework of dynamic capability development (Kreitner.2006; De Geus. 1999).

Senge (1994) also argues that learning organizations as organizations where people continually expand their capacity to create the results they truly desire, where new patterns are maintained and expansive thinking. It can be concluded learning organization is the antecedent for the creation of dynamic capability.

One of the characteristics of a sustainable growth company that is sensitive to changes that represented the company's ability to learn and adapt to environmental changes direction. Learning organization is basically an organization that understands the role and function of the human as a center of excellence to compete in the future. Hence organizational learning is a way to develop the innovation process within the company. In line with Slater and Narver (1995) which states an approach to learning orientation towards value creation.

The ability to learn from each company personnel is a sustainable competitive advantage for the company. The main points in the value creation is a creative and innovation. Creativity and innovation will increasingly be driven through a learning process. When the organization is a habitat conducive learning the creativity and innovation will grow. This situation is very supportive towards value creation (Niklas. 2006; Amit. R, and C. 
Zott. 2001).

The company's ability to develop its capacity through new opportunities and make it into a successful product in the market will certainly improve business performance. While in the company's ability to reconfigure the various resources that will be a core competence is not easily imitated by competitors.

New ways to produce more effective and efficient will improve the company's ability in creating a superior product. In this case the company has an opportunity to create their competitiveness through differentiation or cost leadership simultaneously.

Zollo (2002), said dynamic capability is a learned pattern and collective activity in organization that will generate and modify operating routines to pursue increased effectiveness. Core dynamic capability is the ability of the organization to develop, update and care for a variety of resources (including tangibles, intangibles and human resources) in order to create customer value. Characteristics of sustainable growth companies are sensitive to changes that represented the ability to learn and adapt to the changing environment. Learning organization is basically an organization that understands the role and function of the human as a center of excellence in the future organization. Therefore learning company (organizational learning) is a way to develop the innovation process within the company. In line with Slater and Narver (1995) which states an approach to learning orientation towards value creation.

Liu (2011) showed that the dynamic capabilities as antecedent factors for the development of organizational strategy in which managers alter their resource base, acquire, integrate, and combine resources to produce new value creation strategies. Thus, dynamic capabilities are the drivers behind the creation, evolution, and recombination of other resources into new sources of competitive advantage and firm performance will be maintained and enhanced

Creating customer value is not a short process with a short path. Creating customer value is an integrated process between external opportunities and internal potential. Quality of human resources and technology is needed in quality improvement.

This research has contributed to the development of the concept of market orientation is an important part in creating superior value for customers (value creation). Combination indicator MKTOR (Narver and Slater (1990) and indicators modifications made by Harris (2003) proved to be a valid and reliable measure of the construct of market orientation. Study also confirm the accuracy of LDOQ indicator (the dimensions of learning organization questionnaire) developed by Watkins and Marsick (1997) which has been used in Korea by Yang, 2004, China by Zang et al, 2004, Taiwan by Lien et al., 2006, Latin America by Hernandez., 2006, U.S. by Ellinger et al. 2003.

This study also confirms that the theory of competitive advantage through differentiation or lowcost can be performed simultaneously, especially in situations of high competition. Companies should avoid the situation stuck in the middle when trying to create a symbiosis between differentiation and lowcost into hybrid strategy. Symbiosis between differentiation and low cost is a key element of value creation.

This study also contributes to the development of the theory of dynamic capability which is an arm of the resource base perspective that emphasizes the importance of unique resources and not easily imitated as a source of sustainable competitive advantage. In the context of dynamic capability is the ability of an organization to discover, reconfigure and protect the very resources needed to create products with superior value.

\section{Implications for Management}

Creation is the implementation of a cost advantage and differentiation in silmultan by combining technology and human creativity. In the creative industries group advertising and fashion designer skills in serving the user is the main factor. therefore they should be able to provide excellent customer service. CoCreator as a form of interaction and communication between the designer and the user needs to be strengthened as the basis of competition in terms of service. While the technology is used as a base support competition in terms of cost. For that investment in technology is intended to improve efficiency. In line with the resourcebased view that efficiency would make the company could be flexibility in pricing because the average cost of production is below competitors.

\section{Reference}

[1]. Afuah, A. (2002), "Mapping technological capabilities into product markets and competitive advantage: the case of cholesterol drugs", Strategic Management Journal, Vol. 23, pp. 171-9.

[2]. Afuah, A. (2004). Business Model: A Strategic Management Approach. International Edition. McGrawhill Education

[3]. Amit. R, and C. Zott. (2001). Value creation in e-business. Strategic Management Journal, Vol. 22, No. 6/7, pp. 493-520,

[4]. Barney, J.B. (1991). "Firm Resources And Sustained Competitive Advantage", Journal Of Management, 17(1), Pp. 99-120. The Journal Of International Social Research Volume 3 / 11 Spring 2010

[5]. Barney, Jay. (2007). Resources-Based Theory: creating and sustaining Competitive advantage. Oxford University Press.

[6]. Best R. (2005). Market-Base Management: strategies for growing customer value and profitability. New Jersey: Pearson Education, Inc. 
[7]. Bharadwaj, Sundar G., P. Rajan Varadarajan, and John Fahy. (1993). "Sustainable Competitive Advantage in Service Industries: A Conceptual Model and Research Propositions." Journal of Marketing 57 (October): 83-99.

[8]. Chien-Huang Lin. (2008). The innovativeness effect of market orientation and learning orientation on business performance. International Journal of Manpower. Vol. 29 No. 8 pp. 752-772

[9]. Cravens, David W. Nigel F. Piercy. (2003). Strategic Marketing. $7^{\text {th }}$ ed. McGraw-Hill. New York.

[10]. Cui. Yu and Hao Jiao. (2011). Dynamic capabilities, strategic stakeholder alliances and sustainable competitive advantage: evidence from China. CORPORATE GOVERNANCE Vol. 11 No. 4, pp. 386-398.

[11]. Danneels, E. (2003), “Tight-loose coupling with customers: the enactment of customer orientation”, Strategic Management Journal, Vol. 24, pp. 559-76.

[12]. De Geus Ari. (1999). The Living Company Growth, Learning and Longevity in Business. Nicholas Brealey Publishing Limited

[13]. Dewit, Bob. Meyer, Ron. (2005). Strategy Synthesis: Resolving Strategy Paradoxs to Create Competitive Advantage. First Edition. Thomson Learning.

[14]. Eisenhardt, K.M. and Martin, J.A. (2000), "Dynamic capabilities: what are they?", Strategic Management Journal, Vol. 21, OctoberNovember Special Issue, pp. 1105-21.

[15]. Ellinger, A. D., Ellinger, A. E., Yang, B., \& Howton, S. W. (2002). The relationship between the learning organization concept and firms' financial performance: An empirical assessment. Human Resource Development Quarterly, 13(1), 5-21.

[16]. Farrell Mark Anthony,. (2008). Market orientation, learning orientation and organisational performance in international joint ventures. Asia Pacific Journal of Marketing and Logistics. Vol. 20 No. 3, pp. 289-308

[17]. Harris, L.C. (2003). Measuring market orientation: Exploring a market oriented approach. Journal of Market Focused Management. Vol. 5, pp.239-270

[18]. Helfat, C.E., Finkelstein, S., Mitchell, W., Peteraf, M.A., Singh, H., Teece, D.J. and Winter, S.G. (2007), Dynamic Capabilities: Understanding Strategic Change in Organizations, Blackwell, Oxford.

[19]. Hernandez, M. (2000). The impact of the dimensions of the learning organization on the transfer of tacit knowledge process and performance improvement within private manufacturing firms in Colombia. Unpublished Ph.D. thesis, University of Georgia, Athens.

[20]. Hill. Charles W.L and Garet R. Jones. (2007). Strategic management. Seventh Edition.Houghton Miffin Company. Boston.

[21]. Hitt, Michael A. R. Duane Ireland, and Robert E. Hoskisson. (2007). Strategic Management: Competitiveness and Globalization (Concepts and Cases) Seventh Edition. Thomson Higher Education.

[22]. Hoffman, Nicole P. 2000" An Examination of the "Sustainable Competitive Advantage" Concept: Past, Present, and Future ." Academy of Marketing Science Review Volume No. 4

[23]. Hollensen, Svend. 2010. Marketing Management: a relationship approach. Second edition. Pearson Education.

[24]. Johansson. Niklas, Ulrika Mollstedt. (2006). Revisiting Amit and Zott's model of value creation sources: The SymBelt Customer Center case. Journal of Theoretical and Applied Electronic Commerce Research. ISSN 0718-1876 Electronic Version. VOL 1. ISSUE 3. DECEMBER. page 16 - 27. Universidad de Talca - Chile

[25]. Kim, W Chan. 2011. Blue Ocean Strategy. Cetakan XIII. PT Serambi Ilmu Semesta.

[26]. Kirca, A.H., Jayachandran, S. and Bearden, W.O. (2005), "Market orientation: a meta-analytic review and assessment of its antecedents and impact on performance", Journal of Marketing, Vol. 69 No. 2, pp. 24-41.

[27]. Landroguez Silvia Martelo. (2011). Creating dynamic capabilities to increase customer value. Management Decision Vol. 49 No. 7 , pp. 1141-1159

[28]. Liu.Heng-Yih. (2011). Antecedents and consequences of corporate diversification A dynamic capabilities perspective. Management Decision. Vol. 49 No. 9. pp. 1510-1534

[29]. Moingeon, Bertrand and Amy Edmondson.(1996). Organizational Learning and Competitive Advantage. First published. London. Sage Publication.

[30]. Narver, J.C. and Slater, S.F. (1990), "The effect of a market orientation on business profitability”, Journal of Marketing, Vol. 54, October, pp. 20-35.

[31]. Narver, J.C. and Slater, S.F. (1995), "Market orientation and the learning organization", Journal of Marketing, Vol. 59 No. 7, pp. 6374.

[32]. Niklas Johansson and Ulrika Mollstedt. (2006). Revisiting Amit and Zott's model of value creation sources: The SymBelt Customer Center case, VOL 1 / ISSUE 3 / DECEMBER 2006 / 16 - 27

[33]. Porter, M, E. (1985) Competitive Advantage: Creating and Sustaining Superior Performance. New York: The Free Press.

[34]. Porter, M, E. (1980) Competitive Strategy: Techniques for Analyzing Industries and Competitors. New York : Free Press.

[35]. Sanchez. Jose Angel Lopez, et all. Organisational learning and value creation in business markets. European Journal of Marketing. Vol. 44 No. 11/12, 2010. pp. 1612-1641

[36]. Sutherland, S. (2003), "The public library as a learning organization", available at: www.ifla.org/IV/ifla69/papers/111eSutherland.pdf (accessed 31 May 2011).

[37]. Teece . 2009. Dynamic Capabilities And Strategic Management. First published. Oxford University Press.

[38]. Teece, D.J., Pisano, G. and Shuen, A. (1997), "Dynamic capabilities and strategic management", Strategic Management Journal, Vol. 18 No. 7, pp. 509-33.

[39]. Uncles, M. (2000). Market Orientation, Australian Journal of Management, Vol. 25, No. 2,pp. i-ix.

[40]. Yang, B., Watkins, K., \& Marsick, V. J. (2004). The construct of the learning organization: Dimensions, measurement, and validation. Human Resource Development Quarterly, 15(1),31-55.

[41]. Zhan, W. and Luo, Y. (2008), "Performance implications of capability exploitation and upgrading in international joint ventures", Management International Review, Vol. 48 No. 2, pp. 227-53.

[42]. Zhang, D., Zhang, Z., \& Yang, B. (2004). Learning organization in mainland China: Empirical research on its application to Chinese state-owned enterprises. International Journal of Training and Development, 8(4), 258-273.

[43]. Zollo, M. and Winter, S. (2002), "Deliberate learning and the evolution of dynamic capabilities", Organization Science, Vol. 13 No. 3, pp. 339-51.

[44]. Zubac. Angelina. 2010. The RBV and value creation: a managerial perspective. European Business Review Vol. 22 No. 5, pp. 515 538 
Construct and Indicator

\begin{tabular}{|l|l|}
\hline Construct & Indicator \\
\hline MARKER ORIENTATION & MO1. contribution of each department in the company's \\
& strategy \\
& MO2. Market information shared among departments \\
& MO3. All departments contribute to the creation of \\
& customer value \\
& MO4. priority of customer satisfaction \\
& MO5. responsive to customer needs \\
& MO6. Interactions / actions on competitors' strategies \\
\hline LEARNING & LO1. Continuous Learning \\
ORGANIZATION & LO2. Inquiry and Dialogue \\
& LO3. Team Learning \\
& LO4. Embedded System \\
& LO5. Empowerment \\
& LO6. System Connection \\
& LO7. Strategic Leadership \\
\hline DYNAMIC CAPABILITY & DC1. Opportunity-sensing capability \\
& DC2. Seize opportunities \\
& DC3. reconfiguration capability \\
& DC4. Navigate $\$ managing threats \\
& DC5. Technological flexibility capability \\
\hline Value Creation & Service emphasis: \\
& VC1. Degree of uniqueness, \\
& VC2. Reliability and durability of the product (physically), \\
& VC3. Customer engagement (as co creator), \\
& VC4. Sensitive to the quality of service, \\
& VC5. The content of creative and innovative (Novelty) \\
& \\
& Cost emphasis: \\
& VC6. Degree of cost control (efiensi) \\
& VC7. Degree of engineering capabilities \\
& VC8. Price sensitivity (the price policy flexibility) \\
& VC9. Degree of parity or equity prices against competitors \\
& VC10. Partnerships with suppliers (complementary) \\
& \\
\hline
\end{tabular}

